Park, J. T. \& Hancock, R. (1960). J. gen. Microbiol. 22, 249-258

\title{
A Fractionation Procedure for Studies of the Synthesis of Cell-Wall Mucopeptide and of Other Polymers in Cells of Staphylococcus aureus
}

\author{
By J. T. PARK* aNd R. HANCOCK $\dagger$ \\ M.R.C. Unit for Chemical Microbiology, Department of Biochemistry, \\ University of Cambridge
}

SUMMARY : A method is described for simultaneous estimation of pool constituents, protein, nucleic acids, cell-wall mucopeptide, and possibly teichoic acid in a single sample of $S$. aureus. The method makes possible isolation of the cell-wall mucopeptide contaminated by less than $5 \%$ of the cytoplasmic protein. It is suitable for studies of biosynthesis, with radioactive precursors, and requires approximately $3 \mathrm{mg}$. cell/sample.

The role of the cell wall in maintaining the integrity of bacterial cells is now becoming well understood (Mitchell \& Moyle, 1956), and studies of the synthesis of cell walls are assuming importance particularly because the reactions involved appear to be favourable targets for attack by chemotherapeutic agents (Park, 1958a; Park \& Strominger, 1957). The present knowledge of the composition of bacterial cell walls, though limited, suggests that nearly all such walls contain a mucopolysaccharide-peptide component (hereafter called mucopeptide) which characteristically contains: $N$-acetylglucosamine, $\mathrm{N}$-acetylmuramic acid, D-glutamic acid, $\mathrm{D}$ - and L-alanine and L-lysine or an isomer of diaminopimelic acid (Cummins, 1956; Work, 1957). The cell walls of many Gram-positive species contain, in addition to the mucopeptide, a polyol phosphate polymer which may represent as much as $60 \%$ of the dry weight of the wall (Mitchell \& Moyle, 1951, 1954; Armstrong, Baddiley, Buchanan \& Carss, 1958 a; Armstrong, Baddiley, Buchanan, Carss \& Greenberg, $1958 b$ ). Though in certain organisms the polyol present may be glycerol, the recent work of Armstrong et al. $(1958 a, b)$ suggests that the usual polymer of this type consists of ribitol phosphate with a sugar linked to the ribitol and D-alanine (Dr J. Baddiley, personal communication) bound to the sugar by an ester linkage. This type of polymer found in Gram-positive bacteria has been termed teichoic acid (Armstrong et al. 1958a). In contrast, the walls of many Gram-negative bacteria contain lipoprotein rather than teichoic acid as an additional layer, while possessing a basic structure composed of mucopeptide (Weidel \& Primosigh, 1958). Since it appears that the shape and, in fact, the survival of most bacteria is dependent on the integrity of the mucopeptide component, we sought a method suitable for studying the metabolism of the

* Present address: Department of Microbiology, Vanderbilt University School of Medicine, Nashville 5. Tennessee, U.S.A.

$\uparrow$ Present address : Department of Bacteriology, University of Manchester, Manchester 13, England. 
cell in relation to cell-wall mucopeptide synthesis, and which would enable separation and estimation of mucopeptide simultaneously with other cell components.

The usual method for isolating bacterial cell walls (Dawson, 1949; Salton \& Horne, 1951), although excellent for preparative purposes, is not well suited to studies of their biosynthesis, since cell walls of some organisms may undergo autolysis during the isolation procedure (Mitchell \& Moyle, 1957), and the method does not lend itself readily to quantitative work involving a considerable number of small samples. This paper describes a method evolved for studies of the synthesis of the mucopeptide component of the cell wall of Staphylococcus aureus using ${ }^{14} \mathrm{C}$-labelled amino acids; this method is suitable for fractionation of many small samples of cells, and has been briefly described previously (Hancock \& Park, 1958). By analysis of the appropriate fractions, estimates of acid-soluble pool constituents, alcohol-soluble 'protein', nucleic acids, teichoic acid, protein and mucopeptide can be made on a single sample.

\section{METHODS}

Organisms, growth and harvesting. Staphylococcus aureus strain $\mathbf{H}$ and $S$. aureus strain Duncan were used, the strain used in any particular experiment being stated in the text. $S$. aureus Duncan was grown in medium containing per litre: 20 g. peptone (Difco Bacto); 20 g. glucose; $330 \mathrm{ml}$. inorganic salts solution (Gale, 1947). S. aureus $\mathrm{H}$ was grown in a medium containing, per litre: $5 \mathrm{~g}$. peptone; $5 \mathrm{~g}$. yeast extract; $3 \mathrm{~g}$. $\mathrm{K}_{2} \mathrm{HPO}_{4}$. The $\mathrm{pH}$ value of the media was adjusted to $7 \cdot 2-7 \cdot 4$ before sterilization, and $2 \mathrm{~g}$. glucose, sterilized separately, were added before use. Cultures were grown in flasks shaken at $37^{\circ}$ in a constant-temperature water bath. The extent of growth was followed by determining the optical density of the culture at $700 \mathrm{~m} \mu$ in the Beckman DU spectrophotometer, and the organisms were harvested when the culture was in the exponential phase of growth at a bacterial density equiv. to c. $0.3 \mathrm{mg}$. dry weight $/ \mathrm{ml}$. They were centrifuged at $2000-3000 \mathrm{~g}$ for $15 \mathrm{~min}$. at room temperature, and washed once by a similar centrifugation from distilled water. For the preparation of ${ }^{32} \mathbf{P}$ labelled cell walls, organisms were grown in medium in which tris (2-amino-2-hydroxymethylpropane-1:3-diol) buffer replaced the phosphate normally present; ${ }^{32} \mathrm{P}$ orthophosphate was added to the medium to give a final concentration of $1 \mu \mathrm{mole} / \mathrm{ml}$. and specific activity of $0 \cdot 1 \mu \mathrm{C} / \mu$ mole.

Incorporation of ${ }^{14} \mathrm{C}$ labelled amino acids. Staphylococcus aureus Duncan was harvested and washed, and resuspended in a chemically defined medium (Hancock, 1958) to give the same culture density as that at which the organisms had been harvested. The appropriate ${ }^{14} \mathrm{C}$ amino acid was added to give a final specific activity of $c .0 \cdot 1 \mu \mathrm{C} \mu$ mole, and the culture was shaken at $37^{\circ}$ for the specified time.

Analytical methods. Amino acid analysis were performed on the fractions after hydrolysis with $6 \mathrm{~N}-\mathrm{HCl}$ at $105^{\circ}$ in a sealed tube for $16 \mathrm{hr}$. Before analysing such hydrolysates by paper chromatography, acid was removed 
under an air stream at $45^{\circ}$ and the residue was suspended 2 or 3 times in small volumes of water and redried. Amino acids were estimated by the method of Cocking \& Yemm (1955), except that $\mathrm{M}$-acetate buffer (pH 4.7) replaced citrate buffer; results are expressed relative to a glutamic acid standard.

Hexosamines were separated by the procedure of Boas (1953) after hydrolysis in $6 \mathrm{~N}-\mathrm{HCl}$ for $5 \mathrm{hr}$. at $105^{\circ}$; the resulting fractions were analysed by the method of Schloss (1951).

Paper chromatography. Amino acids were separated by two dimensional chromatography on squares of Whatman no. 4 paper $(25 \mathrm{~cm} . \times 25 \mathrm{~cm}$.), with the solvents recommended by Roberts, Abelson, Cowie, Bolton \& Britten (1955). The papers were sprayed with ninhydrin $(0 \cdot 2 \%,(w / v)$ in acetone) and developed in an air oven at $105^{\circ}$ for $2-3$ min.; the resulting colour was preserved by spraying with $1 \%(\mathrm{w} / \mathrm{v})$ aqueous $\mathrm{CuSO}_{4}$ solution.

For quantitative amino acid analyses, similar papers were sprayed with the ninhydrin reagent of Connell, Dixon \& Hanes (1955) to reveal the positions of the amino acids; they were then sprayed with methanolic borate solution (Connell et al. 1955) and air-dried to remove ammonia. Each area of the paper which contained a single amino acid was cut out and divided into small pieces which were immersed in the ninhydrin reagent for quantitative estimation.

Isotope techniques. Randomly ${ }^{14} \mathrm{C}$-labelled amino acids, and ${ }^{32} \mathrm{P}$ orthophosphate, were obtained from the Radiochemical Centre, Amersham, England.

Radioactivity was determined on samples placed on aluminium planchettes ( $2 \mathrm{~cm}$. diameter) which contained disks of lens tissue; 1 drop of $1 \%$ $(w / v)$ cetyltrimethylammonium bromide was added to each sample, and the samples were dried under a lamp. Samples were plated with less than $1 \mathrm{mg}$. material/sq.cm. on the planchette, so that self-absorption was less than $5 \%$ (Coleman, 1958) and has been neglected. An end-window Geiger-Muller tube and scaler were used in the conventional manner; at least 1000 counts were recorded (standard error of counting $3.3 \%$ ). The abbreviation cpm has been used for counts/minute.

Preparation of cell walls by mechanical disintegration. The procedure of Cummins \& Harris (1956) was used, except that digestion with ribonuclease was omitted. Before depositing the first crude cell-wall fraction, all manipulations were made at $5^{\circ}$; immediately after this point the preparation was heated in a boiling water bath for $10 \mathrm{~min}$. to inactivate any autolytic systems present (Mitchell \& Moyle, 1957). Cell walls containing ${ }^{32} \mathrm{P}$ were washed twice in $0.2 \mathrm{M}$-phosphate buffer ( $\mathrm{pH} \mathrm{6.5)}$ to remove contaminating inorganic ${ }^{32} \mathrm{P}$ before treatment with trypsin.

Enzyme preparations. Crystalline trypsin and pepsin were obtained from the Nutritional Biochemicals Corp.

The lysopeptidase preparation was a gift from Dr M. R. J. Salton and consisted of pure F1 and crude F2 fractions, as used by Salton \& Ghuysen (1957). Potassium phosphate buffer $(0.01 \mathrm{M}, \mathrm{pH} \mathrm{7.0})$, and a temperature of $37^{\circ}$ were used for digestions with this preparation.

Ribonuclease (RNAase) was obtained from the Sigma Chemical Corp. and 
from L. P. Light and Co.; 'Streptodernase' (Lederle Laboratories) was used as a crude deoxyribonuclease (DNAase) preparation. Both enzymes were used at $500 \mu \mathrm{g} . / \mathrm{ml}$. in $0.2 \mathrm{M}-$ phosphate buffer (pH 6.5) at $37^{\circ}$.

\section{RESULTS}

The method devised is similar to the procedure of Roberts et al. (1955) with the important addition that protein and cell-wall mucopeptide in the residual fraction are separated. The method as outlined in Table 1 yields 5 fractions which have been characterized as follows.

Table 1. Scheme for fractionation of Staphylococcus aureus
Fraction
Treatment*
Contents of fraction
1. Cold TCA
Suspend 2.5-3.0 mg. (dry weight) of washed organism in 2 ml. cold water, add $0.5 \mathrm{ml}$. cold $25 \%(w / v)$ trichloroacetic acid (TCA); after $10 \mathrm{~min}$. at $0^{\circ}$ centrifuge at $4000 \mathrm{~g}$ for $5 \mathrm{~min}$., and decant extract
2. Aqueous ethanol-
soluble
3. Hot TCA
4. Trypsin-solubilized
Suspend residue in $2.5 \mathrm{ml} .75 \%$ $(v / v)$ ethanol in water; after $10 \mathrm{~min}$. at room temperature centrifuge $(4000 \mathrm{~g}, 10 \mathrm{~min}$.) and decant extract
Suspend residue in $2.5 \mathrm{ml} .5 \%$ (w/v) TCA, heat $6 \mathrm{~min}$. at $90^{\circ}$, cool, centrifuge $(4000 \mathrm{~g}, 10$ min.) and decant extract
Suspend residue in $0.95 \mathrm{ml}$. $0.05 \mathrm{M}-\mathrm{NH}_{4} \mathrm{HCO}_{3}$ containing $0.005 \mathrm{~N}-\mathrm{NH}_{4} \mathrm{OH}$; add $0.05 \mathrm{ml}$. of solution containing $1 \mathrm{mg}$. crystalline trypsin/ml. Incu- bate $2 \mathrm{hr}$. at $37^{\circ}$ or until diges- tion is complete. Centrifuge $(4000 \mathrm{~g}, 10 \mathrm{~min}$.$) and decant$ extract
5. Residue
Suspend residue in $1.0 \mathrm{ml}$. of water
All low-molecular weight compounds soluble in $5 \%(w / v)$ TCA

\section{Ethanol-soluble 'protein' and lipid}
Breakdown products of nucleic acid and teichoic acid

$$
\begin{aligned}
& \text { Trypsin-degraded } \\
& \text { proteins }
\end{aligned}
$$
Mucopeptide of wall
* The wall of the centrifuge tube is wiped dry after each decantation so as to decrease contamination of the subsequent extract to negligible amounts.

(1) Fraction 1 is the cold trichloroacetic acid (TCA) extract of the cells, which contains the pool amino acids (Hancock, 1958) and other acid-soluble components. A minimum of $2.5 \mathrm{mg}$. (dry weight) cells is used in order to assure well-packed pellets upon centrifugation. After decantation of each extract, residual liquid adhering to the walls of the centrifuge tube is removed by absorption on cotton or paper swabs. In this way, when $2.5 \mathrm{ml}$. of extractant is used, contamination of each extract by material from the previous one should be less than $1 \%$, so that washing of the residue between each extraction is usually unnecessary. 
(2) Extraction of the TCA-insoluble residue with $75 \%(v / v)$ ethanol in water yields a small amount of lipid and 'protein'. In Staphylococcus aureus this 'protein' corresponds to about $0.5 \%$ of the dry weight of the cell, and contains glycine, lysine, alanine and glutamic acid in the approximate proportions $1: 1: 0 \cdot 6: 0 \cdot 6$; these 4 amino acids account for $60 \%$ of the total ninhydrin-reacting material in the fraction after hydrolysis. No other amino acid or amino sugar is present in comparable amount.

(B) Extraction with hot TCA removes nucleic acids from the cells (Park \& Johnson, 1949). This extraction also removes virtually all the teichoic acid from the cell wall, as measured by release of radioactivity from ${ }^{32 P-l a b e l l e d}$ walls. As shown in Fig. $1 a$, over $90 \%$ of the phosphate of isolated cell walls of Staphylococcus aureus Duncan was released by $5 \%$ TCA in 6 min. at $90^{\circ}$. No radioactivity was released from these walls on treatment with RNAase or DNAase. The results in Fig. $1 b$ suggests that some ninhydrin-reacting material
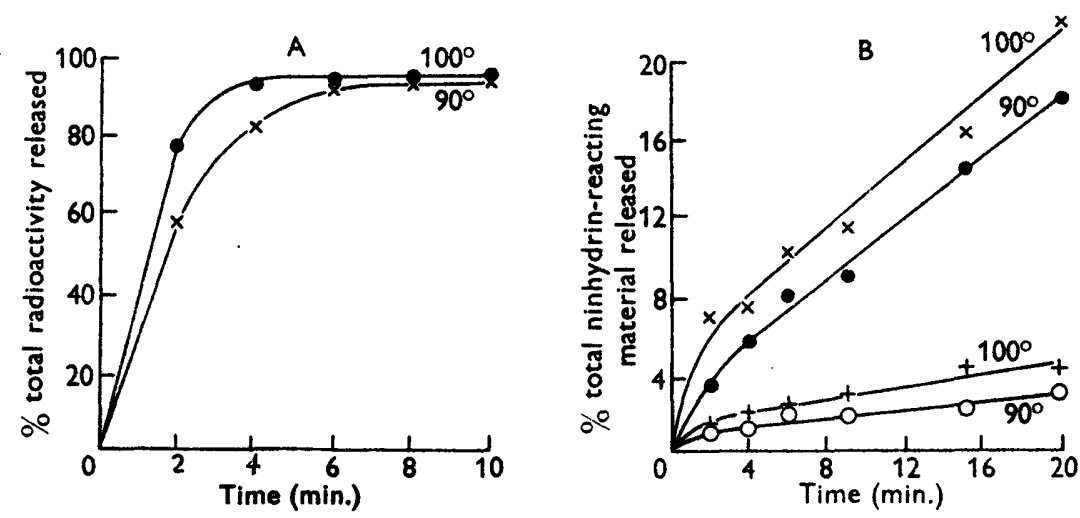

Fig. 1. Release of constituents of cell walls (prepared by Mickle disintegration) of Staphylococcus aureus Duncan during treatment with $5 \%$ (w/v) TCA at $90^{\circ}$ or $100^{\circ}$. At intervels samples of the suspension were cooled rapidly in ice, and centrifuged $(3000 \mathrm{~g}$, $15 \mathrm{~min}$.); samples of the supernatant fluid were taken for estimations. A. Release of radioactivity from walls containing ${ }^{32} \mathbf{P}$. B. Release of ninhydrin-reacting materials, estimated on samples of the supernatant fluid directly $(+, O)$ and on further samples after acid hydrolysis $(x, 0)$.

was released rapidly by hot TCA, and that a slower continued release occurred at a rate of about $5 \%$ of the total ninydrin-reacting material per $6 \mathrm{~min}$. period at $90^{\circ}$. Thus it is possible that this fraction contains as much as $5 \%$ of the amino acids from the cell wall mucopeptide. Since Armstrong et al. (1958) showed that the teichoic acid from $S$. aureus $H$ probably contains $O$-alanyl groups and $\mathrm{N}$-acyl-glucosamine linked together to form a side chain to the ribitol phosphate polymer, measurement of the total alanine or glucosamine released with hot TCA may serve to measure the amount of teichoic acid present. Indeed as the data in Table 2 indicate, considerable amounts of glucosamine and alanine were liberated from" the cells by hot TCA, while muramic acid and glutamic acid which are representative of the mucopeptide component, 
remained with the cell residue. However, though the release of a portion of the glucosamine and alanine paralleled the release of phosphate, quantitative measurements of the release of these three components from isolated cell walls with hot TCA indicated that for every mole of phosphate present in teichoic acid there was only about one-third of a mole each of glucosamine and the associated ester-linked alanine. The amount of ester-linked alanine, measured as the hydroxamate, was approximately equivalent to the glucosamine released by hot TCA. The additional alanine released by hot TCA (Table 2) may have come from the mucopeptide since only about 2 moles of alanine remained in the wall residue per mole of glutamic acid, instead of the 3 moles that might have been expected (Park \& Strominger, 1957). Thus, though ester-linked alanine or glucosamine released by hot TCA may be specific indicators of teichoic acid, the low amounts of these constituents relative to wall phosphate suggest that the glucosamine content per ribitol phosphate unit might be variable. The lysine, glutamic acid, glycine and muramic acid of the wall, which are not associated with the teichoic acid, were released relatively slowly in hot TCA.

Table 2. Distribution of amino sugars and alanine in fractions from Staphylococcus aureus

\begin{tabular}{|c|c|c|c|c|}
\hline Fraction & $\begin{array}{l}\text { Muramic acid; } \\
\% \text { of total }\end{array}$ & $\begin{array}{c}\text { Glucosamine } \\
\text { ( } \mu \text { mole } / 100 \mathrm{mg} . \\
\text { dry wt. } \\
\text { organism) }\end{array}$ & $\begin{array}{c}\text { Alanine } \\
\text { ( } \mu \text { mole } / 100 ~ m g . \\
\text { dry wt. } \\
\text { organism) }\end{array}$ & $\begin{array}{c}\text { Glutamic acid } \\
\text { ( } \mu \text { mole } / 100 \mathrm{mg} . \\
\text { dry wt. } \\
\text { organism) }\end{array}$ \\
\hline Hot TCA extract & $<\mathbf{3}$ & $6 \cdot 5$ & 12 & Trace \\
\hline $\begin{array}{l}\text { Second hot TCA } \\
\text { extract }\end{array}$ & $\mathbf{0} \cdot \mathbf{5}$ & $\mathbf{1 \cdot 3}$ & $\mathbf{3} \cdot \mathbf{8}$ & Trace \\
\hline Wall residue & 96 & $5 \cdot 2$ & 15 & 7 \\
\hline
\end{tabular}

Table 3. Amino acid composition of the trypsin-resistant residue (mucopeptide)

Preparation 1 was from normal organisms, and preparation 2 from organisms grown for $1 \mathrm{hr}$. in the presence of chloramphenicol $(50 \mu \mathrm{g} . / \mathrm{ml}$.); 6.0 $\mathrm{mg}$. dry wt. of organism was used in each case.

Amino acid

Alanine
Glycine
Glutamic acid
Lysine
Total amino acids recovered
Total before separation

$\mu$ mole in wall preparation

$\mathbf{0 . 5 3}$

$1 \cdot 07$

0.28

$0 \cdot 44$

$\mathbf{2 \cdot 3 2}$

$2 \cdot 44$ $\mathbf{0 . 5 8}$

$1 \cdot 90$

0.36

0.57

$\mathbf{3} \cdot 68$ $4 \cdot 02$

(4) Treatment of the hot TCA-insoluble fraction with trypsin (under the conditions described in Table 1) converted about $95 \%$ of the cell protein to soluble peptides. This fraction has not been further characterized. The progress of digestion by trypsin was followed by measurements of the optical density of the preparation (Fig. 2).

(5) The residue consists predominantly of the mucopeptide of the wall structure, as the following evidence indicates. 
(a) After hydrolysis and separation of the amino acids by paper chromatography, $90 \%$ of the ninhydrin-reacting material in the fraction is accounted for by alanine, glycine, glutamic acid and lysine, the characteristic amino acids of Staphylococcus aureus cell walls (Table 3). All the hexosamine of the hot TCA- insoluble fraction of the cell is present in this fraction (Table 4).

Table 4. Incorporation of ${ }^{14} \mathrm{C}$-amino acids into the trypsin-resistant and trypsinsoluble fractions of Staphylococcus aureus Duncan during 45 min. growth in chemically defined medium

\begin{tabular}{|c|c|c|c|c|}
\hline \multirow[b]{2}{*}{${ }^{11} \mathrm{C}$ amino acid } & \multirow{2}{*}{$\begin{array}{c}\text { Final specific } \\
\text { activity } \\
\text { cpm } / \mu \text { mole }\end{array}$} & \multicolumn{3}{|c|}{ Radioactivity of material insoluble in hot TCA, cpm } \\
\hline & & Total & Trypsin-soluble & Trypsin-resistant \\
\hline -Leucine & $\mathbf{2 , 9 0 0}$ & $\mathbf{5 , 1 3 5}$ & 4,917 & 234 \\
\hline -Proline & 6,650 & 4,230 & 4,200 & 14 \\
\hline -Phenylalanine & $\mathbf{9 , 5 6 0}$ & $\mathbf{7 , 1 7 0}$ & 7,050 & 58 \\
\hline Glycine & $\mathbf{3 , 7 5 0}$ & 24,400 & 8,700 & 15,700 \\
\hline -Lysine & 7,180 & 31,400 & $\mathbf{2 1 , 0 5 0}$ & $\mathbf{1 0 , 3 5 0}$ \\
\hline -Alanine & 1,410 & 8,700 & 4,320 & $\mathbf{4 , 3 0 0}$ \\
\hline -Glutamic acid & 8,100 & 29,950 & 20,100 & $\mathbf{5 , 8 5 0}$ \\
\hline ncrease in hexos- & & $1 \cdot 3$ & $\mathbf{0}$ & $1 \cdot 3$ \\
\hline
\end{tabular}

(b) Less than $5 \%$ of the total radioactivity incorporated from ${ }^{14} \mathrm{C}$-labelled non-wall amino acids into the hot TCA-insoluble fraction of growing organisms appeared in this fraction (Table 4).

(c) On treatment with lysopeptidase, an enzyme system which degrades the cell wall of Staphylococcus aureus (Salton \& Ghuysen, 1957), the turbidity of the material in this fraction decreased by $90 \%$ (Fig. 2). From preparations

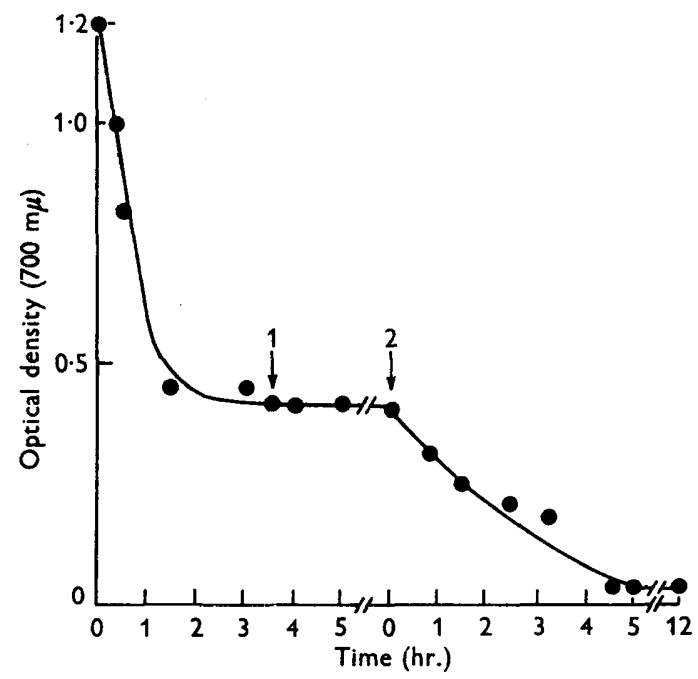

Fig. 2. Digestion of the hot TCA-insoluble residue of Staphylococcus aureus Duncan by trypsin followed by lysopeptidase, as measured by the change in optical density $\left(\log I_{0} / I, 1 \mathrm{~cm}\right.$.) at $700 \mathrm{~m} \mu$. The fraction from $c .1 \mathrm{mg}$. dry wt. organism was incubated in $1 \mathrm{ml}$. with $500 \mu \mathrm{g}$. trypsin; a further $500 \mu \mathrm{g}$. trypsin were added at 1 . After centrifugation $(3000 \mathrm{~g}, 15 \mathrm{~min}$.) and washing (at 2), the residue was resuspended with lysopeptidase $(50 \mu \mathrm{g} . / \mathrm{ml}$.). 
containing ${ }^{14} \mathrm{C}$ in all the wall amino acids, $96 \%$ of the radioactivity became non-sedimentable ( $3000 \mathrm{~g}$ for $\mathbf{3 0} \mathrm{min}$.) and $31 \%$ became dialysable (Table 5 ).

(d) Electron micrographs showed that the material in this fraction consisted of structures which closely resemble cell walls prepared by orthodox methods. However, many of the structures seen in the electron microscope appear to have a further internal layer; it seems likely that, in many cases, this is the part of the wall which is in contact with the electron microscope grid, and which has become distorted as the wall collapsed on to the grid without, apparently, tearing (Plate 1).

Table 5. Effect of digestion with lysopeptidase (50 $\mathrm{gg} . / \mathrm{ml}$.) for $15 \mathrm{hr}$. on some properties of the trypsin-resistant fraction

1. Total $\mathrm{cpm} / \mathrm{ml}$. ( ${ }^{14} \mathrm{C}$-alanine,

After ${ }^{14} \mathrm{C}$-glycine, ${ }^{14} \mathrm{C}$-glutamic acid Control and ${ }^{14} \mathrm{C}$-glycine)

2. Non-sedimentable at $3000 \mathrm{~g}$ for $15 \mathrm{~min}$.; $\mathrm{cpm}$

3. Cpm after dialysis against distilled water $(24 \mathrm{hr}$.)

4. Suspension optical density at $700 \mathrm{~m} \mu$ 15201520 1520

\begin{tabular}{cr}
\multicolumn{1}{c}{43} & \multicolumn{1}{c}{1460} \\
1500 & 1124 \\
0.43 & 0.08
\end{tabular}

Nature of the 'non-cell wall' material in the residue. The removal of that fraction of the residue into which the small degree of incorporation of nonwall amino acids occurred (Table 4) was attempted, without any success, by a number of methods. These included extraction, before or after hot TCA or trypsin treatment, with: methanol and/or ethanol: ether (1:1) for $60 \mathrm{~min}$. at $45^{\circ}$ or $10 \mathrm{~min}$. at boiling point; $75 \%(\mathrm{w} / \mathrm{v})$ or $100 \%$ phenol for $2 \mathrm{hr}$. at $5^{\circ}$ or for $\mathbf{3 0} \mathrm{min}$. at $100^{\circ} ; \mathbf{5 0} \%(\mathrm{v} / \mathrm{v})$ dimethyl formamide; acetone; $10 \%(\mathrm{v} / \mathrm{v})$ or $50 \%(\mathrm{v} / \mathrm{v})$ butanol for $2 \mathrm{hr}$. at $5^{\circ} ; 2 \%(\mathrm{w} / \mathrm{v})$ sodium dodecylsulphate for $2 \mathrm{hr}$. at $37^{\circ}$; replacement of TCA by perchloric acid $\left(1 \mathrm{~N}, 4^{\circ}, 15 \mathrm{hr}\right.$.) for nucleic acid extraction; further digestion with pepsin $(500 \mu \mathrm{g}$. $/ \mathrm{ml}$.) for $14 \mathrm{hr}$. at $\mathrm{pH} 2$.

The nature of this minor component of the trypsin-resistant fraction into which non-wall amino acids are incorporated is unknown; since a structure resembling an underlying layer can be seen in electron micrographs, it is conceivable that in some cases this might be part of the cytoplasmic (protoplast) membrane, although some of the procedures used in attempting to remove it were based on those which have been used to separate lipoprotein from the mucopeptide components of the cell wall of Escherichia coli (Weidel \& Primosigh, 1958).

\section{DISCUSSION}

This extension of previous methods (Roberts et al. 1955) for the chemical fractionation of bacteria separates the mucopeptide of the cell wall of Staphylococcus aureus, which ordinarily accounts for at least $10 \%$ of the dry weight of organisms, from other cellular fractions and enables estimation of the two separate 
polymers of the wall. The resistance of the basic structure of bacterial cell walls, isolated by mechanical disintegration, to digestion by trypsin has been adequately demonstrated (Weidel, 1951; McCarty, 1952; Salton, 1953; 1956; Cummins \& Harris, 1956). Hence, though trypsin may remove protein which is in some cases associated with the wall (such as the M-protein of haemolytic streptococci; Lancefield, 1943), the mucopeptide structure is not attacked. Earlier work (Salton, 1953) indicated that much of the protein of heated suspensions of $S$. aureus is not in a form susceptible to enzymic digestion. However, after treatment with hot TCA, which removes nucleic acids and teichoic acid, the protein becomes susceptible to tryptic digestion, and successful separation of the hot TCA-insoluble fraction into protein and mucopeptide is possible.

The fractionation procedure described here has been found suitable for use with Staphylococcus aureus. We have not investigated its applicability to other organisms, but there is no apparent reason why it should not be suitable for other Gram-positive organisms, at least. It has been applied to studies of the effects of antibiotics on the synthesis of cell-wall mucopeptide (Hancock \& Park, 1958; Park, 1958b) and should be useful in experiments where a comparison is desired of the rates of synthesis of the major classes of high molecular-weight components of the cell (protein, nucleic acids, mucopeptide, teichoic acid).

We wish to thank Dr E. F. Gale, Dr K. McQuillen and the members of the M.R.C. Unit for Chemical Microbiology (Cambridge) for their interest and hospitality during the tenure by J.T.P. of a Senior Post-doctoral Fellowship of the National Science Foundation and by R.H. of an M.R.C. Scholarship.

We are indebted to Mr R. W. Horne (Cavendish Laboratory, Cambridge) for the electron micrographs, and to Dr M. R. J. Salton for a gift of lysopeptidase.

\section{REFERENCES}

Armstrong, J. J., Baddiley, J., Buchanan, J. G. \& Carss, B. (1958a). Nucleotides and the bacterial cell wall. Nature, Lond. 181, 1692.

Armstrong, J. J., Baddruey, J., Buchanan, J. G., Carss, B. \& Greenberg, G. R. $(\mathbf{1 9 5 8 b})$. Isolation and structure of ribitol phosphate derivatives (teichoic acids) from bacterial cell walls. J. chem. Soc. p. 4344.

Boas, N. F. (1953). Method for the determination of hexosamines in tissues. J. biol. Chem. 204, 553.

Cockina, E. C. \& Yemm, E. W. (1955). The determination of amino-acids with ninhydrin. Analyst, 80, 209.

Coleman, G. (1958). Amino acid metabolism of Rhodospirillum rubrum. Ph.D. Dissertation. University of Cambridge.

Connelu, G. E., Dixon, G. H. \& Hanks, C. S. (1955). Quantitative chromatographic methods for the study of enzymic transpeptidation reactions. Canad.J. Biochem. 33, 416.

Cummins, C. S. \& Harris, H. (1956). The chemical composition of the cell wall in some Gram-positive bacteria and its possible value as a taxonomic character. J. gen. Microbiol. 14, 583.

Cummrs, C. S. (1956). The chemical composition of the bacterial cell wall. Int. Rev. Cytol. 5, 25.

Dawson, I. M. (1949). The nature of the bacterial surface. Symp. Soc. gen. Microbiol. 1, 119. 
GaLe, E. F. (1947). The assimilation of amino-acids by bacteria. I. The passage of certain amino-acids across the cell wall and their concentration in the internal environment of Streptococcus faecalis. J. gen. Microbiol. $1,53$.

Hancock, R. (1958). The intracellular amino acids of Staphylococcus aureus: release and analysis. Biochim. biophys. Acta, 28, 402.

Hancock, R. \& PARK, J. T. (1958). Cell-wall synthesis by Staphylococcus aureus in the presence of chloramphenicol. Nature, Lond. 181, 1050.

LANCEFIEID, R. C. (1943). Studies on the antigenic composition of group A hemolytic streptococci. I. Effects of proteolytic enzymes on streptococcal cells. J. exp. Med. 78, 465.

McCarty, M. (1952). The lysis of group A haemolytic streptococci by extracellular enzymes of Streptomyces albus. II. Nature of the cellular substrate attacked by the lytic enzymes. J. exp. Med. 96, 569.

Mitchell, P. \& MoyLe, J. (1951). The glycerophospho-protein complex envelope of Micrococcus pyogenes. J. gen. Microbiol. 5, 981.

Mrtcren, P. \& MoYLE, J. (1954). The gram reaction and cell composition: nucleic acids and other phosphate fractions. J. gen. Microbiol. 10, 533.

Mrtchenc, P. \& Moyle, J. (1956). Osmotic function and structure in bacteria. Symp. Soc. gen. Microbiol. 6, 150.

Mrtchels, P. \& MoyLe, J. (1957). Autolytic release and osmotic properties of 'protoplasts' from Staphylococcus aureus. J. gen. Microbiol. 16, 184.

PARK, J. T. (1958a). Selective inhibition of bacterial cell-wall synthesis; its possible applications in chemotherapy. Symp. Soc. gen. Microbiol. 8, 49.

PARK, J. T. (1958b). Inhibition of cell wall synthesis in Staphylococcus aureus by chemicals which cause accumulation of wall precursors. Biochem. J. 70, 2P.

Park, J. T. \& Johnson, M. J. (1949). Accumulation of labile phosphate in Staphylococcus aureus grown in the presence of penicillin. J. biol. Chem. 179, 585 .

Park, J. T. \& Strominger, J. L. (1957). Mode of action of penicillin. Biochemical basis for the mechanism of action of penicillin and for its selective toxicity. Science, 125, 99.

Roberts, R. B., Abelson, P. H., Cowne, D. B., Bolton, E. T. \& Britten, R. J. (1955). Studies of biosynthesis in Escherichia coli. Publ. Carneg. Instn, no. 607.

Salton, M. R. J. (1953). Cell structure and the enzymic lysis of bacteria. J. gen. Microbiol. 9, 512.

Sarton, M. R. J. (1956). Bacterial cell walls. Symp. Soc. gen. Microbiol. 6, 81.

Salton, M. R. J. \& Horne, R. W. (1951). Studies of the bacterial cell wall. II. Methods of preparation and some properties of cell walls. Biochim. biophys. Acta, 7, 177.

Salton, M. R. J. \& Gruysen, J. M. (1957). Action de l'actinomycetine sur les parois cellulaires bacteriennes. Biochim. biophys. Acta, 24, 160.

Scrloss, B.(1951). Colorimetric determination of glucosamine. Anal. Chem. 23, 1321.

WeIDEL, W. (1951). Über die Zellmembran von Escherichia coli B. I. Präpierung der Membranen. Analytische Daten. Morphologie. Verhalten der Membranen gegenüber den Bakteriophagen der T-Serie. Z. Naturf. 6b, 251.

Weidel, W. \& Primosigh, J. (1958). Biochemical parallels between lysis by virulent phage and lysis by penicillin. J. gen. Microbiol. 18, 513.

Work, E. (1957). Biochemistry of the bacterial cell wall. Nature, Lond. 179, 841.

\section{EXPLANATION OF PLATE}

Electron micrographs of cell-wall preparations obtained by the method described, after washing exhaustively with distilled water. The preparations were air-dried and photographed in the Siemens Elmiskop 1 microscope; the magnifications were: $(a) \times 13,000$; (b) $\times 49,000$. 
Journal of General Microbiology, Vol. 22, No. 1
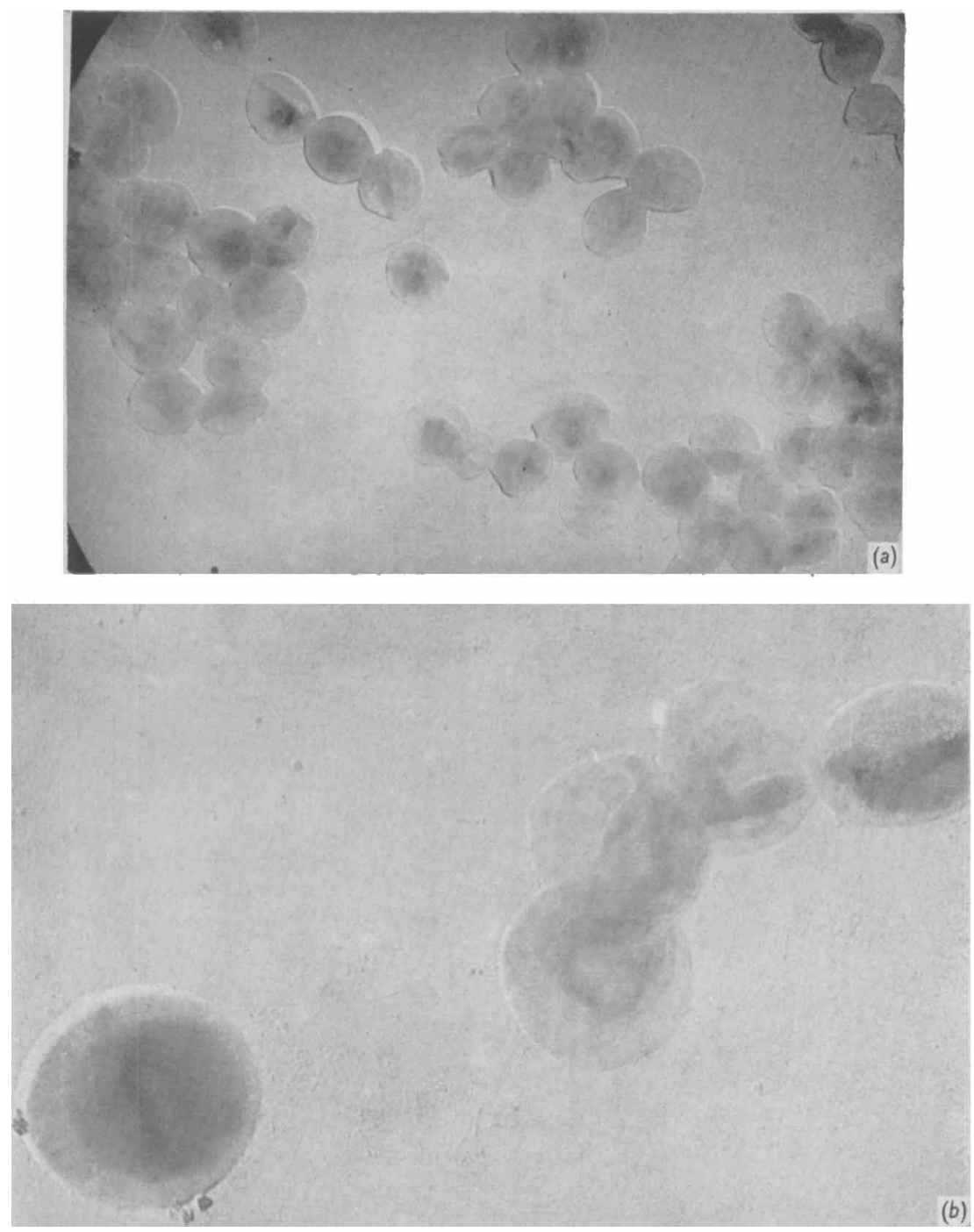

J. T. Park \& R. Hancock-Fractionation of $S$. aureus cells 